\title{
A Survey on the Impact of Instructing Stress and Pronunciation Rules on the Proficiency and Effective Communication among Students of Medicine and Affiliated Fields
}

\author{
Maryam Heydarpour Meymeh, Naghmeh Khadembashi \\ Faculty Member, English Language Department, Faculty of Paramedical Sciences, Shahid Beheshti University \\ of Medical Sceinces, Tehran, Iran \\ mmeymeh@yahoo.com \\ Faculty Member, English Language Department, Faculty of Paramedical Sciences, Shahid Beheshti University \\ of Medical Sceinces, Tehran, Iran \\ nkhadembashi@gmail.com (corresponding author)
}

\begin{abstract}
It has been observed that most students in the field of medicine/medicine-related experience great difficulties in correct pronunciation. Some researchers put emphas is on teaching the phonetic features and phonological rules in order to improve the pronunciation of learners. They have presented so many techniques but unfortunately these techniques have been ignored by most Iranian EFL instructors, and instead, meaning as well as structure has been given more priority. The purpose of this study, therefore, is to detemine whether teaching word stress patterns and pronunciation has any significant effect on more accurate pronunciation and cons equently on the effective and meaningful communication. In this experimental study, 30 Audiology students and 30 Optometry students in their 4th semester who had passed their general English course were used as subjects. 15 out of each group were treated as control and 15 others as Experimental Group. A pre-test was administered based on 1) general proficiency and 2) A word stress test pattern. Treatment (teaching word stress rules) was given to the experimental group while the control group received none. After the treatment, the results based on the two pre-test and post-test were compared and analyzed through SPSS.Results showed that the P value before the treatment was not significant $(P=0.690)$ while the post test which was adminis tered after the treatment was of a noteworthy significance $(P<0.001)$. This indicates the effect of treatment. Regarding the importance of teaching stress and pronunciation patterns, our findings revealed that teaching those rules can be the main reas on fo $r$ fluency and a precise pronunciation, which has been ignored in almost all of the educational syllabi used to teach English to the students of Shahid Beheshti Medical University. Analysis also indicated that subjects in the experimental group possessed a better mean compared to the controlled ones. Also based on the repeated measure analysis, the correlation between the scores before and after treatment was significant $(p<0.001)$.
\end{abstract}

\section{Keywords}

Stress, Proficiency, Pronunciation, Effective Communication

\section{Academic Discipline And Sub-Disciplines}

Education, Teaching, ESL, EFL, ESP

\section{Council for Innovative Research}

Peer Review Research Publishing System

\section{Journal: Journal of Social Sciences Research}

\author{
Vol. 8, No. 3 \\ jssreditor.cir@gmail.com
}

www.jssronline.com 


\section{Introduction}

Pronunciation and stress instruction was absent from the second/foreign language (L2) class room for a long time due to the conventional beliefs that pronunciation is not important, cannot be taught, and can be "picked up" by learners. These beliefs have been questioned and pronunciation teaching has undergone a shift, so that nowadays, its frameworks may encom pass not only linguistic competence, but also discou rse, sociolinguistic, and strategic competence (Morley, 2005). But nowadays, stress and pronunciation instruction is increas ingly being recognized as one of the important components of the L2 classroom. As observed by Pennington (1994, p. 105), the value of pronunciation instruction lies in the fact that it can help leamers develop their interlanguage phonology by giving them "the perceptual and the productive experience they need to reconceptualize the performance targets while offering motivation to change and social experiences to develop a new value set". A survey over the major methods used in language teaching reveals that in all of them, pronunciation and stress play an important role, since they can be recognized as the driving factor of an effecti ve communication. Some of these methods include Direct Method, Naturalistic Approach, Reform Movement,

Audiolingualism and Oral Approach, Cognitive Approach, Silent Way, Community Language Learning Approach and Communicative Approach. In all of these methods, one way or another, stress and pronunciation were emphasized and covered while curriculum writing. Most of these methods acknowledge the importance of the pronunciation component (every approach differently from the previous ones); some of them aim at intelligible pronunciation, rather than total accuracy. Traditional methods of pronunciation teaching are incompatible with the notion that language teaching should be communication-oriented. Despite recognizing the importance of pronunciation teaching, the Communicative Approach followers tended to ignore it, or focus on the suprasegmentals for some time. At present, they recognize the importance of segments and suprasegmentals in the teaching of intelligible pronunciation. Thus, pronunciation tasks $s$ hould appeal to all kinds of learners and aim at an interaction between fluency and accuracy. This can be accomplished with the use of tools of other disciplines, technology developments, the consideration of sociopsychological factors, and the leamers' active participation in the curriculum selection and in the

learning process as a whole. Most of the nowadays syllabi for stress and pronunciation are based on this approach; that is why Communicative Approach is regarded as the milestone for stress and pronunciation teaching patterns.

\section{Materials and Methods}

60 students ( 30 Audiology and 30 Optometry students of Rehabilitation Sciences Faculty) in their $4^{\text {th }}$ semester were randomly selected as subjects. They all had already passed their general English Course. The treatment was administered during their ESP course (English for Specific Purposes). In each group, 15 students were considered as control and 15 others as experimental group. The treatment duration was 20 minutes at the end of each session of the class for the experimental group. The control group received no treatment. The subjects were kept the same all through the study in order to reduce the effect of extraneous variables. The instrument used as assessment tools were as follows:

1. A TOEFL exam used as homogenizing the subjects before the treatment

2. An Oral Stress Test conducted prior to treatment for the purpose of scoring the subjects' production (the whole process was recorded for future use)

3. A number of quizzes following the treatment (teaching stress and pronunciation rules to the experimental group by a single teacher)

4. A stress test administered based on the taught patterns for both experimental and control group including vocabulary test (the vocabularies were tested in two forms: first outside the context and then, within a context)

After the rendering the treatment to the experimental group, both groups undergone the oral tests of stress patterns and pronunciation. The aim was to keep the original pattern of the pre-tests and post-tests identical.

\section{Results}

An independent T-Test was administered before the treatment for the purpose of comparing the control and experimental group. The result showed a $\mathrm{P}=0.690$, indicating a non-significant difference between the two groups. Table 1 shows the statistical measures of the stress test before and after the treatment in both groups. Based on the Repeated Measure Analysis, the subjects' scores before and after the treatment showed significant difference $(P<0.001)$. According to table 1 , the mean score before the treatment was $77.9( \pm 4.859)$, which turned into $82.85( \pm 6.56)$ after the treatment. As seen in Chart 1 , an ordinal interaction between the two variables of time of treatment and the groups were observed. This indicates that the means of the control group before and after treatment were somehow stable, whereas in the experimental group, a significant increase in the mean of the scores after the treatment was observed. 


\section{Estimated Marginal Means of MEASURE_1}

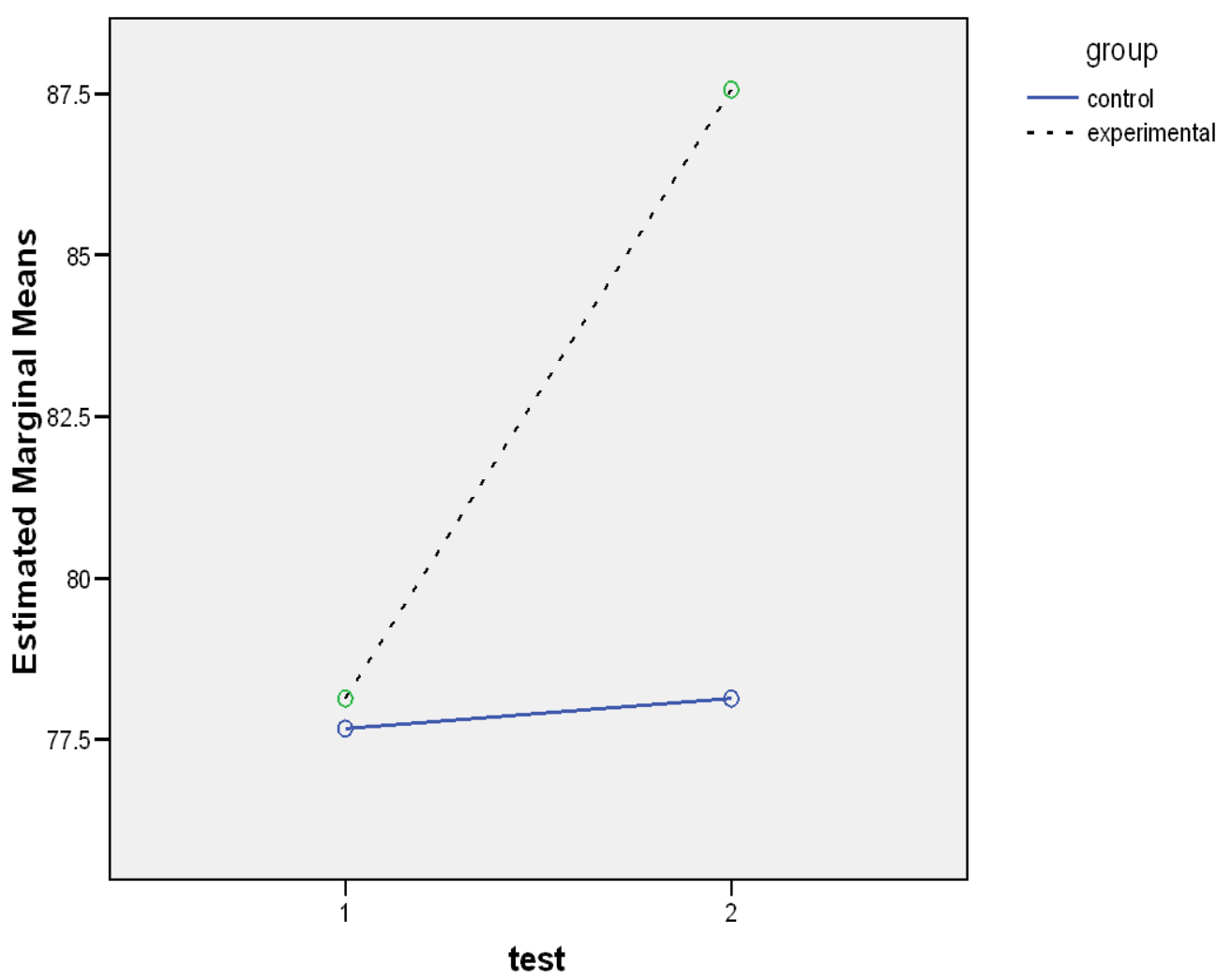

Group Statistics

\begin{tabular}{|ll|r|r|r|r|}
\hline & & & & \multicolumn{2}{c|}{$\begin{array}{c}\text { Std. Error } \\
\text { Mean }\end{array}$} \\
\hline pre & control & $\mathrm{N}$ & Mean & Std. Dev iation & \multicolumn{1}{c|}{ Mroup } \\
& experimental & 30 & 77.67 & 4.859 & .887 \\
\hline
\end{tabular}

Independent Samples Test

\begin{tabular}{|c|c|c|c|c|c|c|}
\hline & \multicolumn{2}{|c|}{$\begin{array}{l}\text { Levene's Test for } \\
\text { Equality of Variances }\end{array}$} & \multicolumn{3}{|c|}{ t-test for Equality of Means } \\
\hline & & $\mathrm{F}$ & Sig. & $\mathrm{t}$ & df & Sig. (2-tailed) \\
\hline pre & $\begin{array}{l}\text { Equal variances } \\
\text { assumed } \\
\text { Equal variances } \\
\text { not assumed }\end{array}$ & 1.739 & .192 & $\begin{array}{l}-.401 \\
-.401\end{array}$ & $\begin{array}{r}58 \\
56.512\end{array}$ & $\begin{array}{l}.690 \\
.690\end{array}$ \\
\hline
\end{tabular}




\section{Within-Subjects Factors}

\begin{tabular}{|l|l|}
\multicolumn{2}{|c|}{ Measure: MEASURE_1 } \\
test & $\begin{array}{l}\text { Dependent } \\
\text { Variable }\end{array}$ \\
\hline 1 & pre \\
2 & post \\
\hline
\end{tabular}

Between-Subjects Factors

\begin{tabular}{|ll|l|r|}
\hline & & Value Label & \multicolumn{1}{|c|}{$\mathrm{N}$} \\
\hline group & 1 & control & 30 \\
& 2 & $\begin{array}{l}\text { experiment } \\
\text { al }\end{array}$ & 30 \\
\hline
\end{tabular}

Descriptive Statistics

\begin{tabular}{|ll|r|r|r|}
\hline & group & Mean & Std. Dev iation & $\mathrm{N}$ \\
\hline pre & control & 77.67 & 4.859 & 30 \\
& experimental & 78.13 & 4.125 & 30 \\
& Total & 77.90 & 4.475 & 60 \\
\hline post & control & 78.13 & 4.890 & 30 \\
& experimental & 87.57 & 4.216 & 30 \\
& Total & 82.85 & 6.566 & 60 \\
\hline
\end{tabular}

\section{Tests of Within-Subjects Effects}

Measure: MEASURE 1

\begin{tabular}{|ll|r|r|r|r|r|}
\hline Source & & \multicolumn{1}{|c|}{$\begin{array}{c}\text { Type III Sum } \\
\text { of Squares }\end{array}$} & df & Mean Square & \multicolumn{1}{c|}{ F } & Sig. \\
\hline test & Sphericity Assumed & 735.075 & 1 & 735.075 & 153.683 & .000 \\
& Greenhouse-Geisser & 735.075 & 1.000 & 735.075 & 153.683 & .000 \\
& Huynh-Feldt & 735.075 & 1.000 & 735.075 & 153.683 & .000 \\
& Lower-bound & 735.075 & 1.000 & 735.075 & 153.683 & .000 \\
\hline test * group & Sphericity Assumed & 603.008 & 1 & 603.008 & 126.072 & .000 \\
& Greenhouse-Geisser & 603.008 & 1.000 & 603.008 & 126.072 & .000 \\
& Huynh-Feldt & 603.008 & 1.000 & 603.008 & 126.072 & .000 \\
& Lower-bound & 603.008 & 1.000 & 603.008 & 126.072 & .000 \\
\hline Error(test) & Sphericity Assumed & 277.417 & 58 & 4.783 & & \\
& Greenhouse-Geisser & 277.417 & 58.000 & 4.783 & & \\
& Huynh-Feldt & 277.417 & 58.000 & 4.783 & & \\
& Lower-bound & 277.417 & 58.000 & 4.783 & & \\
\hline
\end{tabular}


Tests of Between-Subjects Effects

Measure: MEASURE_1

Transf ormed Variable: Av erage

\begin{tabular}{|l|r|r|r|r|r|}
\hline Source & $\begin{array}{c}\text { Type III Sum } \\
\text { of Squares }\end{array}$ & df & Mean Square & \multicolumn{1}{c|}{ F } & \multicolumn{1}{c|}{ Sig. } \\
\hline Intercept & 775216.875 & 1 & 775216.875 & 21313.825 & .000 \\
group & 735.075 & 1 & 735.075 & 20.210 & .000 \\
Error & 2109.550 & 58 & 36.372 & & \\
\hline
\end{tabular}

\section{Discussion}

The presentstudy and its results revealed the importance and effectiveness of having stress and pronunciation patterns in the syllabi of general and ESP courses of English for the students of medicine/medicine-related fields. The results lead us to the fact that including these patterns of teaching in the class syllabus can help students acquire a better fluency over the spoken language, and cons equently it results in effective communication. There were many instances in the post test in which the control group lacked the necessary communicative skill due to the absence of a proper teaching approach towards stress/pronunciation. Since this problem is observed numerously among the faculty members as well as the students, and again, since this lack can cause huge career/academic failures (as in intemational confere nce presentations), incoporating the proper methods for teaching stress/pronunciation patterns to the students can be quite helpful in their class courses, future careers, and academic achievements.

\section{References}

1. PENNINGTON, M.C. Recent research in L2 phonology: implications for practice. In: J. Morley (Org.) Pronunciation pedagogy and theory: new ways, new directions. Illinois: Pentagraph Print, p. 92- 107, 1994.

2. Braithwaite, Merle. (2008). Sounds right. New Zealand: Curriculum Concepts.

3. Brown, A. (2006). Sounds, symbols \& spellings. Singapore: McGraw-Hill (Education) Asia.

4. Dauer, R. (1992). Accurate English. Upper Saddle River, New Jersey: Prentice Hall.

5. Gilbert, J. (1993). Clear speech. Cambridge: Cambridge University Press.

6. Gottlieb, M. (2006). Assessing English language leamers. California: Corwin Press.

7. Hewings, M. (1993). Pronunciation tasks. Cambridge: Cambridge University Press.

8. Thornbury, S. (2005). How to teach speaking. Harlow: Longman.

9. Marinova-Todd, S.H., Marshall, D.B., \& Snow, C.E. (2000). Three misconceptions about age and L2 learning. TESOL Quarterly, 34(1), 9-34.

10. Masgoret, A., \& Gardner, R. (2003). Attitudes, motivation, and second language learning: A meta-analysis of studies conducted by Gardner and associates. Language Learning, 53(Suppl. 2), 167-210.

11. Moyer, A. (2007). Do language attitudes determine accent? A study of bilinguals in the USA. Journal of Multilingual and Multicultural Development, 28(6), 502-518.

12. Moyer, A. (2008). Ultimate attainment in L2 phonology: The critical factors of age, motivation, and instruction. Studies in Second Language Acquisition, 21 (1), 81-108. 